\title{
Characterization and Transcriptional Regulation of n-Alkane Hydroxylase Gene Cluster of Rhodococcus jostii RHA1
}

\author{
Namiko Gibu, Daisuke Kasai *, Takumi Ikawa, Emiko Akiyama and Masao Fukuda ${ }^{\dagger}$ \\ Department of Bioengineering, Nagaoka University of Technology, Nagaoka 940-2188, Japan; \\ gibu@stn.nagaokaut.ac.jp (N.G.); ikawatakun@gmail.com (T.I.); aemlab2012@gmail.com (E.A.); \\ masafuku@isc.chubu.ac.jp (M.F.) \\ * Correspondence: dkasai1@vos.nagaokaut.ac.jp; Tel.: +81-258-47-9427 \\ + Present address: Department of Biological Chemistry, Chubu University, Kasugai 487-8501, Japan.
}

Received: 24 September 2019; Accepted: 21 October 2019; Published: 23 October 2019

\begin{abstract}
Gram-positive actinomycete Rhodococcus jostii RHA1 is able to grow on C10 to C19 n-alkanes as a sole source of carbon and energy. To clarify, the $n$-alkane utilization pathway-a cluster of 5 genes (alkBrubA1A2BalkU) which appeared to be involved in $n$-alkane degradation-was identified and the transcriptional regulation of these genes was characterized. Reverse transcription-PCR analyses revealed that these genes constituted an operon and were transcribed in the presence of $n$-alkane. Inactivation of alkB led to the absence of the ability to utilize $n$-undecane. The alk $B$ mutation resulted in reduction of growth rates on C10 and C12 n-alkanes; however, growths on C13 to C19n-alkanes were not affected by this mutation. These results suggested that $a l k B$ was essential for the utilization of $\mathrm{C} 10$ to $\mathrm{C} 12 n$-alkanes. Inactivation of alkU showed the constitutive expression of alkB. Purified AlkU is able to bind to the putative promoter region of alkB, suggesting that AlkU played a role in repression of the transcription of alk operon. The results of this study indicated that alkB was involved in the medium-chain $n$-alkanes degradation of strain RHA1 and the transcription of alk operon was negatively regulated by alk $U$-encoded regulator. This report is important to understand the $n$-alkane degradation pathway of $R$. jostii, including the transcriptional regulation of alk gene cluster.
\end{abstract}

Keywords: $n$-alkane; $n$-alkane hydroxylase; Rhodococcus; TetR-type transcriptional regulator

\section{Introduction}

Alkanes constitute up to $50 \%$ of crude oil and are commonly found in oil-contaminated environments [1]. Various microorganisms, both aerobic and anaerobic, utilize alkanes as a sole carbon and energy source [2,3]. Aerobic degradation of $n$-alkane is usually initiated by the alkane hydroxylase, which converts alkanes to alkanols [4-6]. The resulting alkanols are oxidized by the sequential reactions of alcohol and aldehyde dehydrogenases to yield the corresponding fatty acids, which are further metabolized by $\beta$-oxidation after conjugation of coenzyme A by an acyl CoA synthetase (Figure 1) [2,3,7]. The alkane-hydroxylation mechanism of Pseudomonas putida GPo1 has been characterized in detail, and consists of three subunits: an integral-membrane non-heme di-iron monooxygenase encoded by alkB; a rubredoxin encoded by duplicated genes, alkF and alkG; and a rubredoxin reductase encoded by alkT [8]. These genes are distributed in two different loci of the OCT plasmid in the strain GPo1 [8]. Their transcription is regulated by LuxR/UhpA-like transcriptional regulator encoded by alkS [8]. In the case of Acinetobacter baylyi ADP1, a three-component alkane hydroxylase containing alkane 1-monooxygenase encoded by alkM, a rubredoxin encoded by rubA, and a rubredoxin reductase encoded by $r u b B$, which is similar to the GPo1 enzyme, catalyzes terminal 
alkane oxidation [9,10]. Transcription of alkM depends strictly on AraC/XylS-like transcriptional activator encoded by alkR and is induced by alkanes of various chain lengths [11].

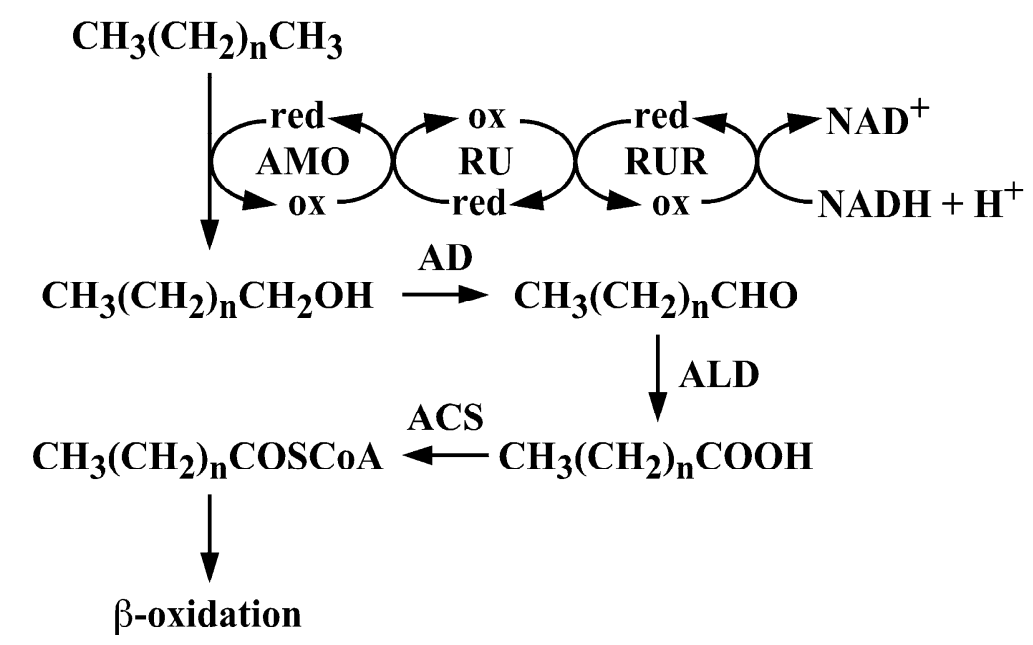

Figure 1. Aerobic pathways for the $n$-alkane degradation by terminal oxidation. Abbreviations: AMO, n-alkane 1-monooxygenase; RU, rubredoxin; RUR, rubredoxin reductase; AD, alcohol dehydrogenase; ALD, aldehyde dehydrogenase; ACS, acyl-CoA synthetase; ox, oxidized; and red, reduced.

Other types of alkane-hydroxylation mechanism have also been reported. A flavin-binding monooxygenase encoded by alm $A$ is responsible for oxidation of C32 and C36n-alkanes in Acinetobacter sp. DSM17874 [12]. In Geobacillus thermodenitrificans NG80-2, a soluble monomeric monooxygenase encoded by ladA, is involved in oxidation of C15 to C36n-alkanes [13]. CYP153-family cytochrome P450 monooxygenases have been reported to catalyze terminal $n$-alkane oxidation in Acinetobacter sp. EB104, Mycobacterium sp. HXN-1500, and Alcanivorax dieselolei B-5 [5,14,15].

Mycolic acid-containing actinomycetes, including Rhodococcus, have been increasingly recognized as candidates for the biodegradation of hydrocarbons because of their capacity to degrade a wide range of organic compounds and to produce biosurfactants, hydrophobic cell surface, and ubiquity and robustness in the environment [16]. Recently, alkB homologs, which codes for alkane 1-monooxygenase, have been characterized in actinomycetes, including Rhodococcus opacus B-4 [17], Rhodococcus ruber SP2B [18], Rhodococcus sp. BCP1 [19], Rhodococcus sp. TMP2 [20], Rhodococcus sp. NRRL B-16531 [21], Rhodococcus erythropolis Q15 [21], Gordonia sp. SoCg [22,23], and Nocardioides sp. CF8 [4]. However, little is known about the catabolic operon structure and regulatory mechanism of $n$-alkane degradation genes in actinomycetes. In this study, $n$-alkane degradation genes in Rhodococcus jostii RHA1 were examined. Strain RHA1 was isolated from a lindane-contaminated soil, and it co-metabolizes polychlorinated biphenyls with biphenyl via the biphenyl metabolic pathway [24,25]. It utilizes a wide range of hydrocarbons-such as aromatic compounds, propane, and steroids-as a sole source of carbon and energy [26-29]. In this study, we found that RHA1 utilized C10 to C19 n-alkanes, and characterized the operon structure and transcriptional regulation of $n$-alkane degradation genes in RHA1.

\section{Materials and Methods}

\subsection{Bacterial Strains, Plasmids, and Culture Conditions}

The bacterial strains and plasmids used in this study are listed in Table 1. Rhodococcus jostii RHA1 and its mutant derivatives were routinely grown at $30{ }^{\circ} \mathrm{C}$ in Luria-Bertani (LB) medium, $0.2 \times \mathrm{LB}$ medium, or W minimal salt medium [30] containing 10 or $20 \mathrm{mM} n$-alkanes (C9 to C30) or $20 \mathrm{mM}$ pyruvate. In solid cultures on $\mathrm{W}$ minimal medium agar, $n$-alkanes ( $\mathrm{C} 5$ to $\mathrm{C} 13$ ) were supplemented as vapor. Escherichia coli strains were grown in LB medium at $37^{\circ} \mathrm{C}$. For cultures of cells carrying 
antibiotic resistance markers, the media for E. coli transformants were supplemented with $100 \mathrm{mg}$ of ampicillin/liter or $25 \mathrm{mg}$ of kanamycin/liter.

Table 1. Strains and plasmids used in this study.

\begin{tabular}{|c|c|c|}
\hline Strain or Plasmid & Relevant Characteristic(s) ${ }^{a}$ & Source or Reference \\
\hline \multicolumn{3}{|l|}{ Strains } \\
\hline \multicolumn{3}{|l|}{ R. jostii } \\
\hline RHA1 & Wild type & [25] \\
\hline $\mathrm{DAB}$ & RHA1 derivative; $\triangle$ alk $B$ & This study \\
\hline DAU & RHA1 derivative; $\triangle a l k U$ & This study \\
\hline \multicolumn{3}{|l|}{ E. coli } \\
\hline JM109 & $\begin{array}{c}\text { endA1 recA1 gyrA96 thi hsdR17 relA1 supE44 } \Delta(\text { lac-proAB) } m c r A \\
{\left[\mathrm{F}^{\prime}, \text { traD36 proAB }{ }^{+} \text {lacl }{ }^{\mathrm{q}} \Delta \mathrm{ZM} 15\right]}\end{array}$ & {$[31]$} \\
\hline S17-1 & RK2 tra regulon, $\lambda$ pir, host for pir-dependent plasmids & [32] \\
\hline BL21(DE3) & $\begin{array}{l}\mathrm{F}^{-} \text {ompT hsdS } S_{\mathrm{B}}\left(\mathrm{r}_{\mathrm{B}}^{-} \mathrm{m}_{\mathrm{B}}^{-}\right) \text {gal dcm (DE3); T7 RNA polymerase } \\
\text { gene under the control of the lacUV5 promoter }\end{array}$ & [33] \\
\hline \multicolumn{3}{|l|}{ Plasmids } \\
\hline pT7Blue & Cloning vector; $\mathrm{T} 7$ promoter, $\mathrm{Ap}^{\mathrm{r}}$ & Novagen \\
\hline pBluescript II KS(+) & Cloning vector; $\mathrm{Ap}^{\mathrm{r}}$ & [34] \\
\hline pK19mobsacB & oriT $\operatorname{sac} B \mathrm{Km}^{\mathrm{r}}$ & [35] \\
\hline $\mathrm{pK} 4$ & Rhodococcus-E. coli shuttle vector, $\mathrm{Km}^{\mathrm{r}}$ & [36] \\
\hline pET16b & Expression vector, $\mathrm{N}$-terminal His 10 tag, Ap $^{\mathrm{r}} \mathrm{T} 7$ promoter & Novagen \\
\hline pTALKBL & $\begin{array}{l}\text { pT7Blue with a 917-bp PCR fragment generated by alkBL_F/R } \\
\text { primer pair }\end{array}$ & This study \\
\hline pTALKBR & $\begin{array}{l}\text { pT7Blue with a 723-bp PCR fragment generated by alkBR_F/R } \\
\text { primer pair }\end{array}$ & This study \\
\hline pTALKBLR & pTALKBR with a 733-bp EcoRI-SacI fragment of pTALKBL & This study \\
\hline pABSmobsacB & $\begin{array}{l}\text { pK19mobsacB with a 1.5-kb EcoRI-HindIII fragment of } \\
\text { pTALKBLR }\end{array}$ & This study \\
\hline pTALKBD & $\begin{array}{l}\text { pT7Blue with a 967-bp PCR fragment generated by alkBD_F/R } \\
\text { primer pair }\end{array}$ & This study \\
\hline pT7BL & pT7Blue with a 0.8-kb EcoRI-BamHI fragment of pTALKBL & This study \\
\hline pT7B & pT7BL with a 0.7-kb BamHI-HindIII fragment of pTALKBD & This study \\
\hline pK4ALKB & pK4 with a 1.5-kb EcoRI fragment of pT7B & This study \\
\hline pTUPU & $\begin{array}{l}\text { pT7Blue with a 761-bp PCR fragment generated by } \\
\text { UPalkU_F/R primer pair }\end{array}$ & This study \\
\hline pTDWU & $\begin{array}{l}\text { pT7Blue with a 792-bp PCR fragment generated by } \\
\text { DWalkU_F/R primer pair }\end{array}$ & This study \\
\hline pKU & $\begin{array}{l}\text { pK19mobsacB with a 1.6-kb HindIII fragment carrying part of } \\
\text { alkU }\end{array}$ & This study \\
\hline pETALKU & pET16b with a 0.7-kb PCR amplified fragment carrying of alkU & This study \\
\hline
\end{tabular}

${ }^{\mathrm{a}}$ Abbreviations; $\mathrm{Ap}^{\mathrm{r}}$ and $\mathrm{Km}^{\mathrm{r}}$, resistance to ampicillin and kanamycin, respectively.

\subsection{DNA Manipulations, Nucleotide Sequencing, and Sequence Analysis}

Total DNA isolation and electroporation were performed as described in a previous study [37]. DNA sequencing was performed by the Eurofins sequencing service (Eurofins Genomics, Tokyo, Japan). Analysis of nucleotide sequences and homology searches were carried out as previously described [38]. The genome sequence of RHA1, whose accession numbers are NC_008268, NC_008269, 
NC_008270, and NC_008271, was used to find $n$-alkane catabolic genes at the RHA1 genome database (http://www.rhodococcus.ca/index.jsp).

\subsection{Construction of Disruption Mutants}

The alkB and alkU genes were separately disrupted using the $s a c B$ counterselection system essentially as described previously [29,35,39]. Oligonucleotides that amplified flanking regions of each gene were listed in Table 2. Disruption of the genes was examined by PCR analysis. Disruption of the genes was confirmed by diagnostic PCR using specific primer sets and subsequently by DNA sequencing of the PCR amplified regions flanking the deletions.

Table 2. Primer sequences used in this study.

\begin{tabular}{|c|c|}
\hline Primer & Sequence $\left(5^{\prime} \text { to } 3^{\prime}\right)^{a}$ \\
\hline alkB_F & TGACGACGTCGAATATCAGC \\
\hline alkB_R & CCTGAATGATCAGGAACGG \\
\hline alkBrubB_F & GAGCATTCACAACGATGTGC \\
\hline alkBrubB_R & ACAGGAAGTCCTTCGACACC \\
\hline rubA2B_F & GTACCGATTTCAAGCTCTACC \\
\hline rubA2B_R & CACATCCGATGAGACCTCC \\
\hline rubBalkU_F & ACGGTCGAAGTTGGAGTGC \\
\hline rubBalkU_R & CTTTGTAGATCGTCTGCCTGC \\
\hline alkU_F & CGAGCGACAGAGTCGATACC \\
\hline alkU_R & ATGAAACTCAAGGCGAGCC \\
\hline alkBL_F & ACAGGTGAAGCTACCAGCG \\
\hline alkBL_R & GTGAGAGCTTCTGGACTTTCC \\
\hline alkBR_F & CTTCGGTGAGAGCTTCTGG \\
\hline alkBR_R & AAGCTTGTCGTCGGGCACATCG (HindIII) \\
\hline alkBD_F & 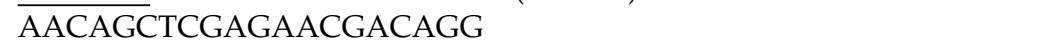 \\
\hline alkBD_R & GAATTCCATCACCGAACTCCGC (EcoRI) \\
\hline UPalkU_F & AAGCTTTGTCCTCGCTCGACGTGAGC (HindIII) \\
\hline UPalkU_R & GGATCCATTGTCGGCCAGGGACGTTCG (BamHI) \\
\hline DWalkU_F & GGATCCAACGGTCGTGGGTGAACTCG (BamHI) \\
\hline DWalkU_R & AAGCTTAGGAACTGATCTACGCCAACC (HindIII) \\
\hline HISalkU_F & TCGAAGGTCGTCATAGCAGACGACCGCACCGCAGACGACCGCACC \\
\hline HISalkU_R & GGATCCTCGAGCATAAAGTACTCACGGGTGAAGTACTCACGGGTG \\
\hline
\end{tabular}

\subsection{Growth Curves on n-Alkanes}

RHA1 and its mutant derivatives were grown in $10 \mathrm{~mL}$ of $0.2 \times \mathrm{LB}$ medium for $36 \mathrm{~h}$ at $30^{\circ} \mathrm{C}$. Cells were harvested and washed three times with $\mathrm{W}$ medium and suspended in the same medium. Afterwards, the bacterial suspension was inoculated in $50 \mathrm{~mL}$ of $\mathrm{W}$ medium supplemented with 10 or $20 \mathrm{mM} n$-alkanes. The cells were incubated at $30^{\circ} \mathrm{C}$ under shaking conditions and at each time point 1 -mL aliquots were sampled and centrifuged at $5000 \times g$ and the pellet was dried to a constant weight.

\subsection{Resting Cell Assay}

RHA1 and DAB were grown on $0.2 \times \mathrm{LB}$ or $\mathrm{W}$ minimal medium containing $20 \mathrm{mM}$ pyruvate or $10 \mathrm{mM} n$-alkanes to give an $\mathrm{OD}_{600}$ of 1.0. The cells were collected by centrifugation, washed twice with $2 \mathrm{~mL}$ of $\mathrm{W}$ medium, and resuspended in a same medium to give an $\mathrm{OD}_{600}$ of 1.0. One milliliter of cell suspension was preincubated for $5 \mathrm{~min}$ at $30^{\circ} \mathrm{C}$ and was incubated in a sealed $4.5-\mathrm{mL}$ glass vial with shaking at $30^{\circ} \mathrm{C}$ after the addition of $1 \mathrm{mM}$ of $n$-alkanes. Control cells were inactivated by being autoclaved at $121^{\circ} \mathrm{C}$ for $15 \mathrm{~min}$ prior to the addition of substrate. To stop the reaction $0.1 \mathrm{~mL}$ of $6 \mathrm{~N} \mathrm{HCl}$ was added to the mix and $1 \mathrm{mM}$ of phenanthrene was added as an internal standard. After the addition of $\mathrm{NaCl}$ to saturation, $3 \mathrm{~mL}$ of ethyl acetate was added to the mixture, which was then mixed on a vortex mixer for $1 \mathrm{~min}$. The supernatant was recovered, dehydrated with sodium sulfate, 
evaporated, and dissolved in $150 \mu \mathrm{L}$ of ethyl acetate. One microliter of extract was analyzed by gas chromatography-mass spectrometry (GC-MS; model 5971A; Agilent Technologies Co., Palo Alto, CA, USA), equipped with an Ultra-2 capillary column (50 m by $0.2 \mathrm{~mm}$; Agilent Technologies) as described previously [25].

\subsection{RNA Isolation}

RHA1 and alkU-deficient mutant (DAU) were grown at $30^{\circ} \mathrm{C}$ in $100 \mathrm{~mL}$ of $\mathrm{W}$ medium containing $10 \mathrm{mM} n$-undecane or $20 \mathrm{mM}$ pyruvate. The resulting cells were harvested by centrifugation, washed with RNA protect bacterial reagent (QIAGEN, Germantown, MD, USA), and stored at $-80^{\circ} \mathrm{C}$. Total RNA extraction from frozen cells was performed as described previously [40]. Purified RNA was then treated with RNase-free DNase I (Takara Bio Inc., Otsu, Japan) to remove contaminating DNA.

\subsection{Reverse Transcription (RT)-PCR and Quantitative RT-PCR ( $q R T-P C R$ )}

Single-stranded cDNA was synthesized from $1.0 \mu \mathrm{g}$ of total RNA utilizing ReverTra Ace reverse transcriptase (Toyobo, Osaka, Japan) with random primers (Invitrogen, Carlsbad, CA, USA) in a 20- $\mu \mathrm{L}$ reaction mixture. PCR amplification was performed using $2.0 \mu \mathrm{L}$ of the cDNA mixture, specific primers (Table 2), and Ex Taq DNA polymerase (Takara Bio Inc.) under the following conditions: $95^{\circ} \mathrm{C}$ for $30 \mathrm{~s}$ and 30 cycles of $95^{\circ} \mathrm{C}$ for $30 \mathrm{~s}, 60^{\circ} \mathrm{C}$ for $60 \mathrm{~s}$, and $72^{\circ} \mathrm{C}$ for $60 \mathrm{~s}$. A control without reverse transcriptase was used for each reaction to verify the absence of genomic DNA contamination. Samples from the PCR were electrophoresed on a $2.0 \%$ agarose gel and visualized with ethidium bromide.

The amount of each transcript was measured using StepOne Plus real-time PCR system (Life Technologies, Carlsbad, CA, USA). Each primer set was designed using Primer Express version 3.0 software (Life Technologies). For qRT-PCR, $100 \mathrm{ng}$ of cDNA sample, $100 \mathrm{nmol}$ of each primer (Table 2), and $10 \mu \mathrm{L}$ Fast SYBR Green PCR Master Mix (Life Technologies) were mixed in a final volume of $20 \mu \mathrm{L}$. The qRT-PCR was carried out using the following conditions: $95^{\circ} \mathrm{C}$ for 20 sec and 40 cycles of $95^{\circ} \mathrm{C}$ for $3 \mathrm{sec}$ and $60^{\circ} \mathrm{C}$ for $30 \mathrm{sec}$. The fluorescence signal from SYBR Green I intercalating into double-stranded DNA was detected during each annealing step. The copy number of each gene was determined based on the standard curve of the target gene, which was estimated by the results of qRT-PCR performed using 10-fold serial dilutions of each standard sample. To normalize the amount of RNA in each sample, 16S rRNA was used as an internal standard. Each measurement was carried out in triplicate, and the means and standard deviations were calculated.

\subsection{Purification of His-Tagged alkU}

The coding region of alkU was amplified by PCR using the specific primer pair (Table 2). The amplified fragment was cloned into NdeI-BamHI-digested pET16b by using In-Fusion cloning strategy [41]. The cells of E. coli BL21 (DE3) harboring the resultant plasmid (pETALKU) were grown at $30{ }^{\circ} \mathrm{C}$. Expression of the gene was induced by adding $0.5 \mathrm{mM}$ isopropyl- $\beta$-D-thiogalactopyranoside when the absorbance at $600 \mathrm{~nm}\left(A_{600}\right)$ of the culture reached 0.5. After 4-h induction, the cells were harvested by centrifugation at $5000 \times g$ at $4{ }^{\circ} \mathrm{C}$ for $10 \mathrm{~min}$ and were resuspended in $50 \mathrm{mM}$ Tris- $\mathrm{HCl}$ buffer (pH 7.5). The cells were then disrupted by an ultrasonic disintegrator (UD-201; Tomy Seiko Co., Tokyo, Japan) and centrifuged at $15,000 \times g$ at $4{ }^{\circ} \mathrm{C}$ for $15 \mathrm{~min}$, to generate crude cell extract.

To remove nucleic acids, streptomycin sulfate was added to the crude extracts to a final concentration of $1 \%$. The lysate was kept on ice for $10 \mathrm{~min}$ and centrifuged at $15,000 \times g$ for $15 \mathrm{~min}$. The supernatant was applied to a Ni Sepharose 6 Fast Flow column (GE Healthcare, Buckinghamshire, UK) previously equilibrated with buffer A consisting of $50 \mathrm{mM}$ Tris- $\mathrm{HCl}$ (pH 7.5), $500 \mathrm{mM} \mathrm{NaCl}$, and $100 \mathrm{mM}$ imidazole. Proteins were allowed to bind for $1 \mathrm{~min}$ at $4{ }^{\circ} \mathrm{C}$ while rotating, followed by washing five times in $5 \mathrm{~mL}$ of buffer A. His-tagged proteins were eluted with $5 \mathrm{~mL}$ of buffer B consisting of $50 \mathrm{mM}$ Tris- $\mathrm{HCl}$ (pH 7.5), $500 \mathrm{mM} \mathrm{NaCl}$, and $500 \mathrm{mM}$ imidazole, and the fractions were pooled and concentrated. 


\subsection{Electrophoretic Mobility Shift Assays (EMSAs)}

DNA fragments containing the upstream region of alkB were prepared by PCR with the specific primer pairs (Table 2). The $3^{\prime}$ ends of the probe fragments were labeled with DIG-11-ddUTP using the second-generation DIG gel shift kit (Roche), according to the manufacturer's instructions. Binding reaction was performed at $20^{\circ} \mathrm{C}$ for $20 \mathrm{~min}$ in a $10-\mu \mathrm{L}$ reaction mixture containing $50 \mathrm{ng}$ of the purified his-tagged AlkU (His-AlkU), $1 \mathrm{nM}$ DIG-labeled probe, $1 \mu \mathrm{g}$ of poly[d(I-C)], $0.1 \mu \mathrm{g}$ of poly-L-lysine, $20 \mathrm{mM}$ HEPES ( $\mathrm{pH}$ 7.6), $1 \mathrm{mM}$ EDTA, $10 \mathrm{mM}\left(\mathrm{NH}_{4}\right)_{2} \mathrm{SO}_{4}, 1 \mathrm{mM}$ dithiothreitol, $0.2 \%(w / v)$ Tween 20 , and $30 \mathrm{mM} \mathrm{KCl}$. Gel electrophoresis and the detection of signals were performed as described previously [42].

\section{Results}

\subsection{Growth of RHA1 on n-Alkanes}

To determine growth characteristics of RHA1 on $n$-alkanes, RHA1 was grown in liquid W minimal medium containing $10 \mathrm{mM} n$-alkanes ranging in length from $\mathrm{C} 9$ to $\mathrm{C} 30$ and on $\mathrm{W}$ medium agar supplemented with $\mathrm{C} 5$ to $\mathrm{C} 13$ as vapor. RHA1 grew on $\mathrm{C} 11$ to $\mathrm{C} 19$ n-alkanes in liquid medium (Table 3). It did not grow on C9, C10, C20, and C30 n-alkanes in liquid medium. On agar medium, it grew on $n$-decane in addition to $\mathrm{C} 11$ to $\mathrm{C} 13 n$-alkanes. It did not grow on $\mathrm{C} 5$ to $\mathrm{C} 9 n$-alkanes on agar medium. Based on these results, we concluded that RHA1 utilized C10 to C19n-alkanes as a sole source of carbon and energy.

Table 3. Growth of R. jostii RHA1 and DAB on $n$-alkanes.

\begin{tabular}{|c|c|c|c|c|c|c|c|c|c|c|c|c|c|c|c|c|c|c|}
\hline \multirow{2}{*}{ Media } & \multirow{2}{*}{ Strains } & \multicolumn{17}{|c|}{$n$-Alkanes ${ }^{a}$} \\
\hline & & C5 & C6 & $\mathrm{C} 7$ & $\mathrm{C} 8$ & C9 & C10 & C11 & $\mathrm{C} 12$ & C13 & C14 & C15 & C16 & $\mathrm{C} 17$ & C18 & C19 & $\mathrm{C} 20$ & C30 \\
\hline \multirow{2}{*}{ Liquid } & RHA1 & ND & ND & ND & ND & - & - & + & + & + & + & + & + & + & + & + & - & - \\
\hline & $\mathrm{DAB}$ & ND & ND & ND & ND & ND & - & - & \pm & + & + & + & + & + & + & + & - & - \\
\hline \multirow{2}{*}{ Solid } & RHA1 & - & - & - & - & - & + & + & + & + & ND & ND & ND & ND & ND & ND & ND & ND \\
\hline & $\mathrm{DAB}$ & ND & ND & ND & ND & ND & \pm & - & \pm & + & ND & ND & ND & ND & ND & ND & ND & ND \\
\hline
\end{tabular}

\subsection{The alk Gene Cluster of Strain RHA1}

A BLASTp homology search using the amino acid sequence of alkane 1-monooxygenase (AlkB) from R. opacus B-4 (YP_002779449) as a query indicated that its closest ortholog is ro02534 in the genome database of RHA1. Hence, ro02534 was named as alkB. The region downstream of ro02534 contained orthologs of genes involved in $n$-alkane catabolism. Based on the amino acid sequence similarities, ro02535, ro02536, and ro02537 encode a couple of rubredoxins and a rubredoxin reductase, responsible for electron transfer in alkane hydroxylase [43], and were named as $r u b A 1, r u b A 2$, and $r u b B$, respectively (Figure 2A). The ro02538 gene located next to $r u b B$ showed similarity to a putative TetR-type transcriptional regulator, and was named as alkU.

To examine operon structure of the alk gene cluster, RT-PCR analysis was performed with total RNA prepared from RHA1 cells grown on either $n$-undecane or pyruvate. Amplification products with the expected sizes of the segments alkB, alkB-rubB, rubA2-rubB, rubB-alkU, and alkU were detected using RNA prepared from the cells grown on $n$-undecane (Figure 2B). Based on these results, alkB, $r u b A 1, r u b A 2, r u b B$, and alkU might be included in the same transcriptional unit. No amplification products were detected when RNA from pyruvate-grown cells was used, suggesting that transcription of these genes is induced after growth on $n$-undecane. 
A

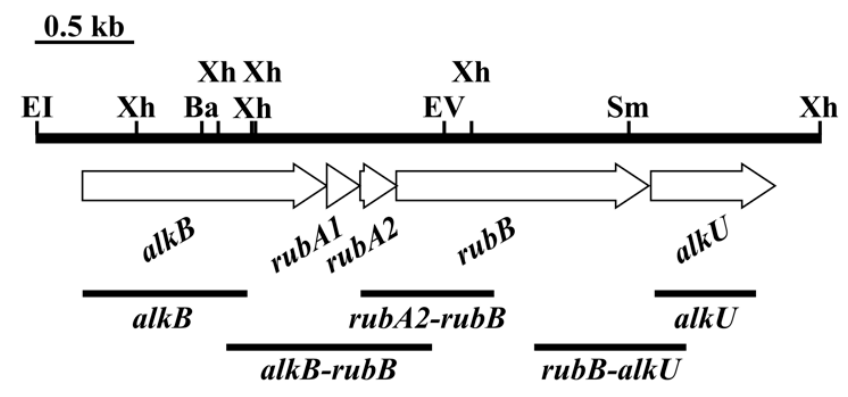

B

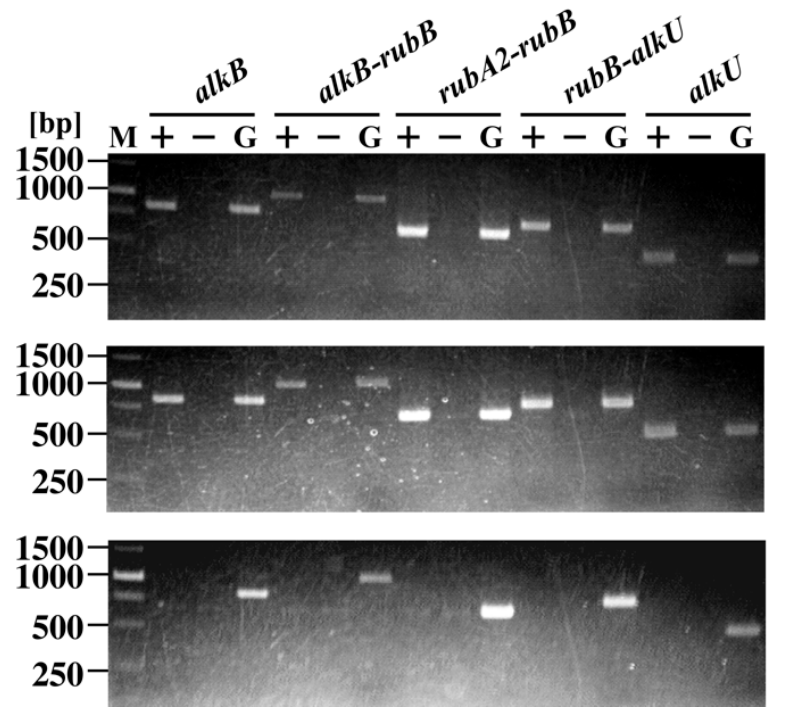

Figure 2. Organization and RT-PCR analysis of the alk gene cluster in RHA1. (A) Open arrows indicate the sizes, locations, and transcriptional directions of ORF. Boldfaced bars below the gene cluster diagram indicate the locations of the amplified RT-PCR products shown in panel B. Abbreviations for restriction enzymes: Ba, BamHI; EI, EcoRI; EV, EcoRV; Sm, SmaI; and Xh, XhoI. (B) Total RNA used for cDNA synthesis was isolated from RHA1 cells grown on $n$-undecane (upper panel), $n$-hexadecane (middle panel), and pyruvate (lower panel). Agarose gel electrophoresis of RT-PCR assays with primers targeting alkB (expected size, $831 \mathrm{bp}$ ), alkB-rubA1-rubA2-rubB (expected size, $1039 \mathrm{bp}$ ), rubA2-rubB (expected size, $671 \mathrm{bp}$ ), rubB-alkU (expected size, $766 \mathrm{bp}$ ), and alkU (expected size, $510 \mathrm{bp}$ ) are shown. Positions of amplified regions and primer sequences are indicated in panel A and Table 2, respectively. Lane M, molecular weight markers; Lanes + and -, RT-PCR with and without RT, respectively; lane G, control PCR with the RHA1 genomic DNA.

\subsection{Disruption of alkB in RHA1}

In order to evaluate the role of alkB in $n$-alkane utilization of RHA1, alkB was inactivated by gene replacement technique with the alkB disruption plasmid, pABSmobsacB. The degradation activities of the resting cells of RHA1 and the resulting mutant, DAB, toward $n$-undecane were determined by GC-MS. As shown in Figure 3A, DAB almost completely lost the activity to degrade $n$-undecane under the assay conditions used. To determine if this deficiency was caused by the disruption of alkB, a plasmid, pK4ALKB, containing an intact alkB was introduced into DAB to complement the mutation. Complementation with alkB restored these degradation activities to a level approximately equal to that of the wild-type strain (Figure 3A). Based on this result, we concluded that alkB was essential for degradation of $n$-undecane. In contrast, $n$-hexadecane degradation activity of DAB was almost the same as that of RHA1 (Figure 3B), suggesting that alkB was not essential for the utilization of $n$-hexadecane, and other gene(s) were involved in this degradation. However, the cells of DAB 
harboring pK4ALKB showed a higher activity than that of the wild-type strain. It is therefore probable that the alkB product has the ability to degrade $n$-hexadecane.
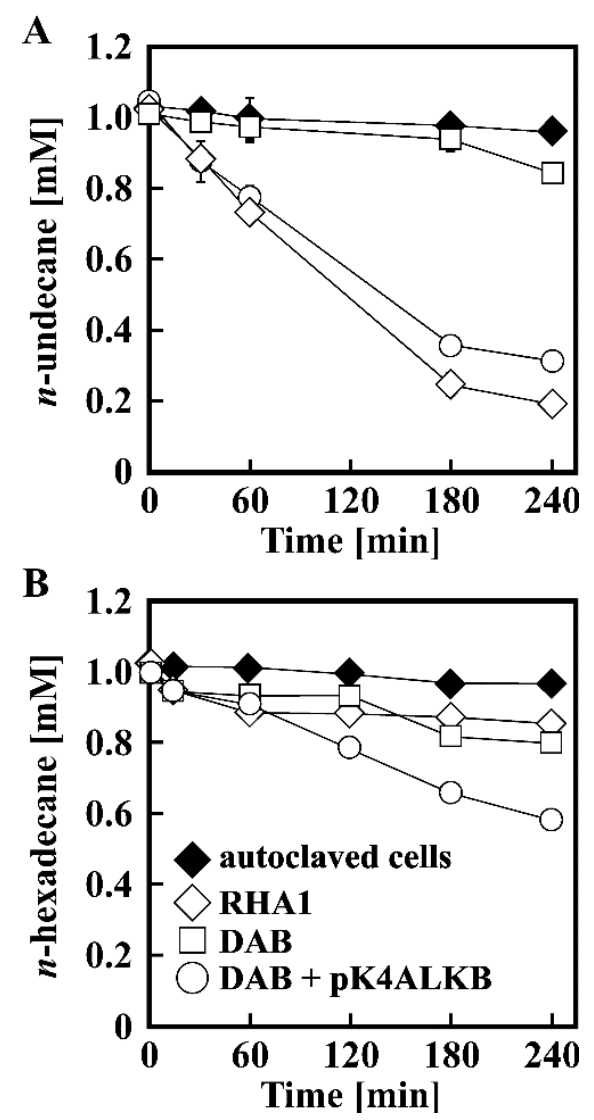

Figure 3. Degradation of $n$-undecane (A) and $n$-hexadecane (B) by RHA1, DAB, and DAB harboring pK4ALKB. $1 \mathrm{mM}$ of each $n$-alkanes was incubated with the resting cells of RHA1 (open diamonds), DAB (open squares), DAB harboring pK4ALKB (open circles), and autoclaved cells of RHA1 (closed diamonds). The degradation activities were determined by GC-MS analysis. Each value is the average \pm standard deviation of three independent experiments.

To estimate the level of participation of alkB in the growth of RHA1 on $n$-alkane, the growth ability of DAB was compared to that of RHA1. The capacity of DAB to grow in both liquid and solid media containing $n$-undecane was completely lost (Figure 4 and Table 3). When the alkB mutation was complemented by the introduction of the corresponding gene in trans, the growth deficiency was restored. When DAB was grown in $n$-dodecane and $n$-decane, the growths decreased (Table 3 ). These results indicated that alkB is fundamentally engaged in the utilization of C10 to C12 n-alkanes. On the other hand, disruption of alkB did not affect the growth on $n$-alkane from C13 to C20 (Table 3), suggesting that other gene(s) were involved in the $n$-alkanes utilization. 
A

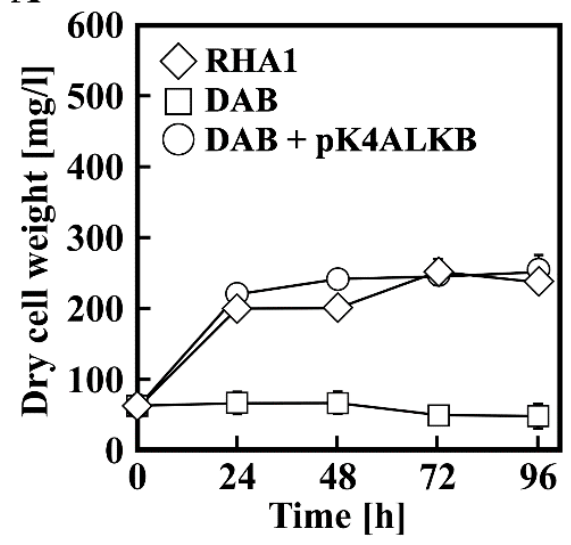

C
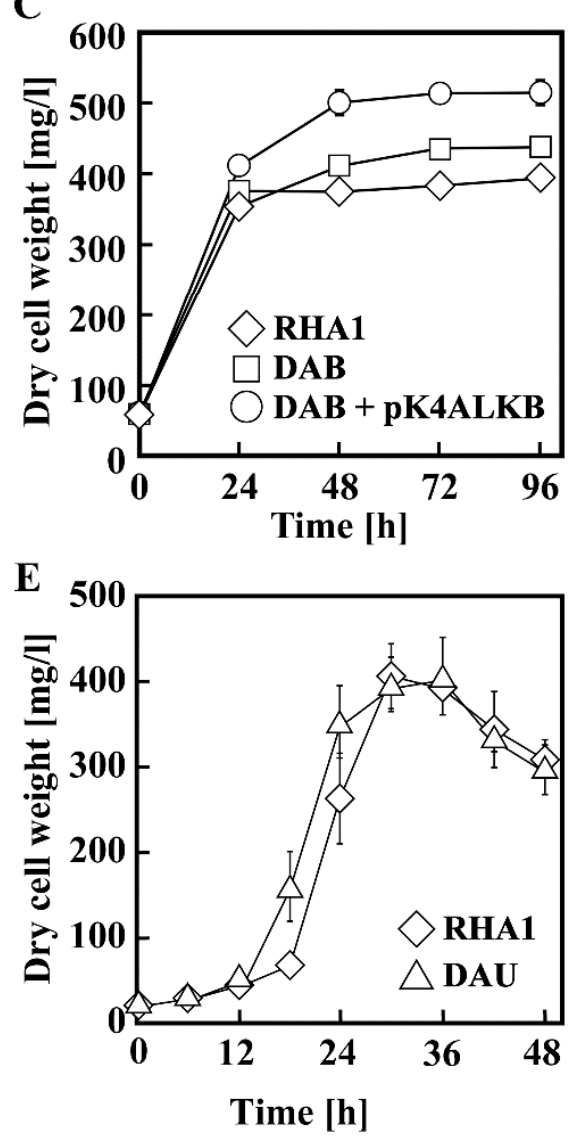

B

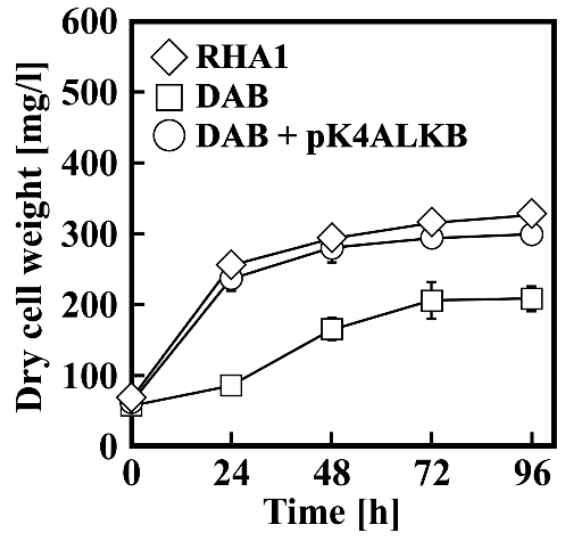

D

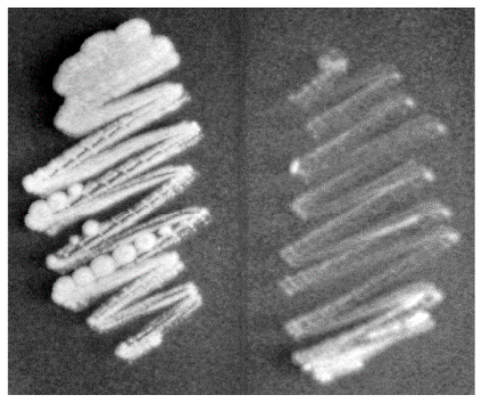

Figure 4. Growth of RHA1 and its mutant derivatives on $n$-undecane (A), $n$-dodecane (B), $n$-hexadecane (C), and $n$-decane (D). (A-C) RHA1 (diamonds), DAB (squares), DAB harboring pK4ALKB (circles) were grown in $\mathrm{W}$ medium containing $10 \mathrm{mM}$ of each $n$-alkanes. Each value is the average \pm standard deviation of three independent experiments. (D) Growth of RHA1 (left) and DAB (right) on $n$-decane after 5 days of incubation. (E) Growth of RHA1 (diamonds) and DAU (triangle) on $20 \mathrm{mM} n$-undecane.

\subsection{Transcriptional Regulation of alk Operon}

The alkU gene product (AlkU) is similar in sequence to putative transcriptional regulators belonging to the TetR family from Rhodococcus sp. Q15 (AAK97457) and R. opacus B-4 (BAH50508). To confirm that alkU gene product played a role in the transcriptional regulation of the alk operon, alk $U$ was disrupted by homologous recombination. The growth ability on $n$-undecane of the resulting mutant strain DAU was slightly higher than that of the wild-type strain (Figure 4E). The results suggest 
that AlkU negatively regulated the transcription of alk genes and was responsible for the induction of these genes.

To examine AlkU function, the level of transcription of alkB in strain DAU was examined by quantitative RT-PCR. When the RHA1 cells grew on pyruvate, mRNAs of alkB was not detected in our analytical condition (Figure 5). On the other hand, the transcription was significantly increased in the cells grown on $n$-undecane, indicating that the transcription of the alk genes was induced during $n$-undecane utilization. In contrast, DAU cells showed constitutive expression of alkB (Figure 5). The results suggest that AlkU was essential for the transcriptional regulation of alk operon as a repressor.

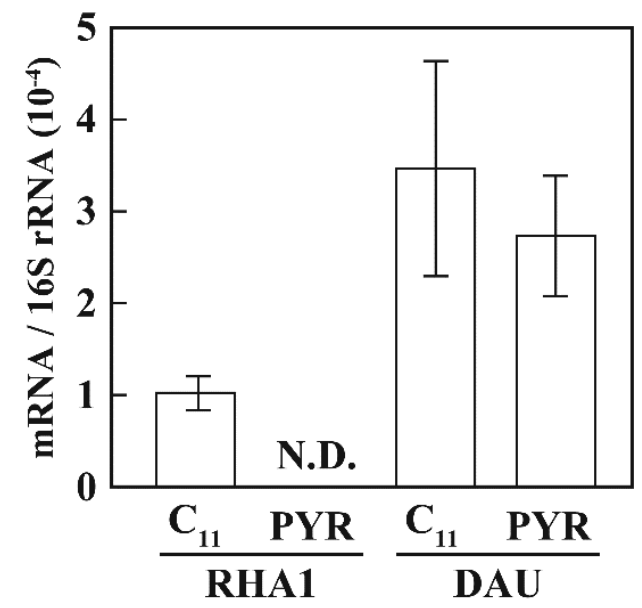

Figure 5. qRT-PCR analysis of the expression of alkB in RHA1 and DAU. The cells of RHA1 and DAU were grown in $\mathrm{W}$ medium containing $10 \mathrm{mM}$-undecane (C11) or $20 \mathrm{mM}$ pyruvate (PYR). Values for each mRNA expression were normalized to $16 \mathrm{~S}$ rRNA gene expression. The data are mean values \pm standard deviations for three independent experiments. N.D.: Not detected.

His-tag fused alkU was expressed in E. coli BL21 (DE3) cells to produce His-tagged AlkU (His-AlkU). SDS-PAGE analysis revealed the expression of a 25.3-kDa protein, consistent with the deduced amino acid sequence (Figure 6). Purified His-AlkU was used in electrophoretic mobility shift assays (EMSAs) with DNA probes containing the upstream region of alkB (Figure 7A). His-AlkU bound this DNA region (Figure 7B), indicating that the direct binding of AlkU with the promoter region of the alk operon.

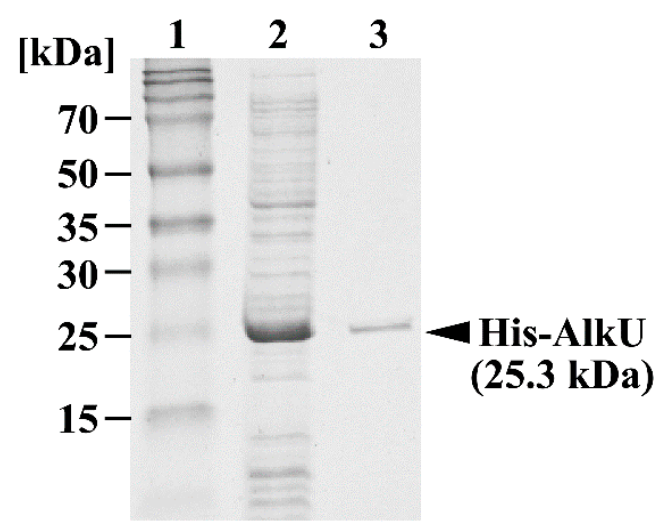

Figure 6. SDS-PAGE analysis of protein fraction. Lanes: 1, molecular-weight markers; 2, Crude cell extract of E. coli BL21 (DE3) harboring pETALKU (10 $\mu \mathrm{g}$ of protein); 3, Elution fraction including His-AlkU ( $2 \mu \mathrm{g}$ of protein). 
A

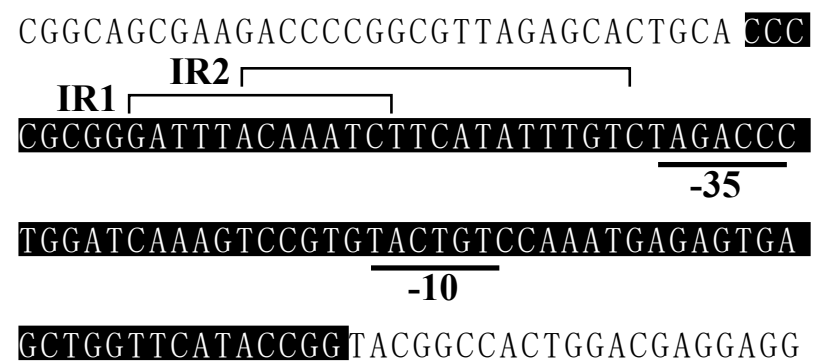

\section{TTCGGATCGTG}

B

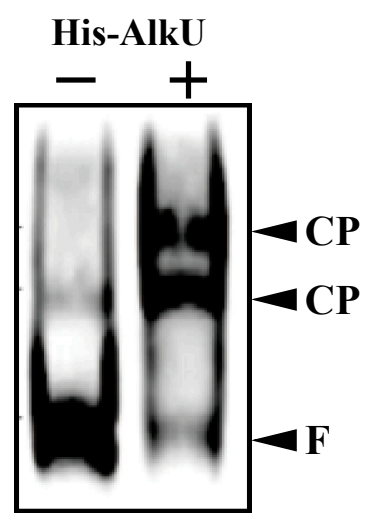

Figure 7. Binding of His-AlkU to the upstream region of alkB. (A) Schematic diagrams of the upstream region of alkB. Black boxes revealed the region of DNA probe used in EMSAs. Underlines indicate a putative -10 and -35 sequences. Open box indicates start codon of alkB. Putative IR sequences are shown on top of nucleotide sequences. (B) EMSAs of the binding of purified His-AlkU (50 ng) to the DNA probe. The positions of the free probe and His-AlkU-DNA complex are shown by F and CP, respectively. + and - indicate presence and absence of His-AlkU, respectively.

\section{Discussion}

In this study, we identified and characterized the alkB gene and its transcriptional regulation in $R$. jostii RHA1, which could grow on $n$-alkanes ranging in length from $\mathrm{C} 10$ to $\mathrm{C} 19$ as the sole source of carbon and energy. Though RHA1 grows on propane [29], this strain is unable to utilize C5 to C9 $n$-alkanes. Similar observations have been reported for R. opacus B-4 and Rhodococcus sp. BCP1, which are unable to grow on $\mathrm{C} 5$ to $\mathrm{C} 6$ and $\mathrm{C} 8$ to $\mathrm{C} 11 n$-alkanes, respectively $[17,19]$. These observations may indicate that the hydroxylases for $\mathrm{C} 5$ to $\mathrm{C} 9 n$-alkanes degradation are absent in RHA1.

In the deduced amino acid sequence of alkB, the conserved eight-histidine motif thought to be required for catalytic activity of non-heme di-iron integral membrane alkane hydroxylases was detected [44,45]. Kyte-Doolittle hydropathy analysis of the amino acid sequence deduced from AlkB of RHA1 showed similarity to those of other Rhodococcus strains and P. putida GPo1 [46], suggesting that AlkB of RHA1 was membrane bound (data not shown). AlkB of GPo1 oxidizes $n$-alkanes limited to $\mathrm{C} 13$ and has a bulky amino acid-like tryptophan at position 55 [47]. On the other hand, alkane 1-monooxygenase from Rhodococcus sp. strain NRRL B-16531, R. erythropolis Q15, and Mycobacterium tuberculosis $\mathrm{H} 37 \mathrm{Rv}$, with valine or leucine residue at the corresponding position, were shown to oxidize $n$-alkanes up to at least C16 [21,47]. Since leucine residue was found at the position of AlkB from RHA1, and the $n$-hexadecane degradation activity increased by introduction of alkB on a multicopy-number plasmid, this enzyme might be responsible for the long-chain $n$-alkane degradation. However, the growth on $n$-alkanes from C13 to C19 was not affected by deletion of alkB, whereas the alk $B$ transcription was observed during the growth with $n$-hexadecane. It is suggested that alk $B$ is a minor contributor to $\mathrm{C} 13$ to $\mathrm{C} 19 n$-alkanes utilization, and unidentified gene(s) played a major role in the degradation of these $n$-alkanes.

AlkM from Acinetobacter sp. strain ADP1 oxidizes C12 to C18 n-alkanes [11]. Acinetobacter sp. strain M-1 was shown to possess two alkane monooxygenases encoded by alkMa and alkMb, involved in the degradation of up to C16 and C30n-alkanes, respectively [48]. In addition, AlmA from Acinetobacter sp. strain DSM 17874 [12], LadA from G. thermodenitrificans NG80-2 [13], and cytochrome P450 monooxygenases $[5,14,15]$ were reported to be involved in long-chain $n$-alkane degradation. In silico mining of the RHA1 genome database revealed the genes encoding for five AlmA homologs, a LadA homolog, and 31 putative cytochrome P450 monooxygenases. According to the deduced amino acid sequence similarity, some of these genes seemed to be responsible for C13 to C19n-alkane utilization in RHA1. 
The organization of alk genes is similar to that of the genes from several Rhodococcus strains $[17,19,21]$, demonstrating that the gene clusters appear to have a common ancestral origin. RT-PCR analysis revealed that alkB, rubA1, rubA2, rubB, and alkU are transcribed as an operon (Figure 2B). The transcripts of these genes were observed in cells growing on both $n$-undecane and $n$-hexadecane, suggesting that the transcription of the alk operon was induced by these $n$-alkanes or their metabolites. In qRT-PCR analysis revealed the transcriptional induction of alk operon during the growth on $n$-undecane (Figure 5). The operon was constitutively transcribed in the absence of alkU. Furthermore, the EMSA revealed that AlkU bound the upstream region of alkB (Figure 7). These results strongly suggested that alkU codes for a repressor of the alk operon. In several Gram-negative bacteria, the transcriptions of the alk genes are under the control of a LuxR-type transcriptional regulator, AlkS binding the inverted repeat (IR) sequences located in directly upstream of the -35 region of alkB and alkS promoters $[8,49,50]$. In contrast, AlkU belongs to the TetR family of transcriptional regulators that regulate the transcription of genes for antibiotic resistance, antibiotic biosynthesis, catabolic pathway, and biofilm formation in Gram-negative and Gram-positive bacteria [51]. TetR-type transcriptional regulators are known to act both as a repressor and an activator [51,52]. TetR, which is involved in the transcriptional repression of tetracycline resistance gene, tet $A$, is known to act as a homodimer and binds the palindromic operator overlapping with the tet $A$ and $\operatorname{tet} R$ promoters [53,54]. Furthermore, LuxR of Vibrio harveyi activates and represses the transcription of quorum-sensing genes by binding palindromic sequences located upstream or downstream of the promoter regions [52]. In the case of the alkB promoter region of Rhodococcus strains-including RHA1, BCP1, and B-4-two IR sequences, IR1 (GATTTacAAATC) and IR2 (ACAAATcTtcAtATTTGT), are well conserved [17,19], suggesting that AlkU may recognize to the IR sequences, in order to control the transcription of the alk operon. Since two different AlkU-DNA complexes were observed, AlkU may interact with multiple binding sites in the promoter in the same manner as other TetR family proteins [55]. The IR2 sequence is located immediately upstream of a putative -35 (TAGACC) sequence. Therefore, the transcription of alk genes appeared to be inhibited by the AlkU binding to the promoter region. It has been reported that the transcription of alkB of BCP1 and B-4 is also activated in the presence of $n$-alkanes $[17,19]$. The transcriptional regulation of the alk genes from these Rhodococcus stains was similar to that from RHA1.

In this study, we identified the alk operon involved in the medium-chain $n$-alkanes degradation of strain RHA1. According to the mutant analysis of alkB, the gene is required for the growth on C10 to $\mathrm{C} 12 n$-alkanes. The alkU gene encodes a transcriptional repressor of alk operon, and $n$-alkanes act as inducers. It is necessary to identify the long-chain $n$-alkane oxidation genes in order to gain a better understanding of $n$-alkane degradation by this strain.

Author Contributions: N.G., D.K., and M.F. designed the study. N.G. and D.K. wrote the manuscript. N.G., E.A., and T.I. performed the experiments and analyzed the data. All authors reviewed the paper.

Funding: This research was funded by Nagaoka University of Technology Presidential Research Grant.

Conflicts of Interest: No potential conflict of interest was reported by the authors. The funders had no role in the decision to publish the results.

\section{References}

1. Leahy, J.G.; Colwell, R.R. Microbial degradation of hydrocarbons in the environment. Microbiol. Rev. 1990, 54, 305-315. [PubMed]

2. Rojo, F. Degradation of alkanes by bacteria. Environ. Microbiol. 2009, 11, 2477-2490. [CrossRef] [PubMed]

3. Wentzel, A.; Ellingsen, T.E.; Kotlar, H.K.; Zotchev, S.B.; Throne-Holst, M. Bacterial metabolism of long-chain n-alkanes. Appl. Microbiol. Biotechnol. 2007, 76, 1209-1221. [CrossRef] [PubMed]

4. Hamamura, N.; Yeager, C.M.; Arp, D.J. Two distinct monooxygenases for alkane oxidation in Nocardioides sp. strain CF8. Appl. Environ. Microbiol. 2001, 67, 4992-4998. [CrossRef]

5. Maier, T.; Forster, H.H.; Asperger, O.; Hahn, U. Molecular characterization of the 56-kDa CYP153 from Acinetobacter sp. EB104. Biochem. Biophys. Res. Commun. 2001, 286, 652-658. [CrossRef] 
6. Maeng, J.H.; Sakai, Y.; Tani, Y.; Kato, N. Isolation and characterization of a novel oxygenase that catalyzes the first step of $n$-alkane oxidation in Acinetobacter sp. strain M-1. J. Bacteriol. 1996, 178, 3695-3700. [CrossRef]

7. Watkinson, R.J.; Morgan, P. Physiology of aliphatic hydrocarbon-degrading microorganisms. Biodegradation 1990, 1, 79-92. [CrossRef]

8. $\quad$ van Beilen, J.B.; Panke, S.; Lucchini, S.; Franchini, A.G.; Rothlisberger, M.; Witholt, B. Analysis of Pseudomonas putida alkane-degradation gene clusters and flanking insertion sequences: Evolution and regulation of the alk genes. Microbiology 2001, 147, 1621-1630. [CrossRef]

9. Geissdörfer, W.; Kok, R.G.; Ratajczak, A.; Hellingwerf, K.J.; Hillen, W. The genes rubA and rubB for alkane degradation in Acinetobacter sp. strain ADP1 are in an operon with estB, encoding an esterase, and oxyR. J. Bacteriol. 1999, 181, 4292-4298.

10. Ratajczak, A.; Geissdörfer, W.; Hillen, W. Alkane hydroxylase from Acinetobacter sp. strain ADP1 is encoded by alkM and belongs to a new family of bacterial integral-membrane hydrocarbon hydroxylases. Appl. Environ. Microbiol. 1998, 64, 1175-1179.

11. Ratajczak, A.; Geissdörfer, W.; Hillen, W. Expression of alkane hydroxylase from Acinetobacter sp. strain ADP1 is induced by a broad range of $n$-alkanes and requires the transcriptional activator AlkR. J. Bacteriol. 1998, 180, 5822-5827. [PubMed]

12. Throne-Holst, M.; Wentzel, A.; Ellingsen, T.E.; Kotlar, H.K.; Zotchev, S.B. Identification of novel genes involved in long-chain $n$-alkane degradation by Acinetobacter sp. strain DSM 17874. Appl. Environ. Microbiol. 2007, 73, 3327-3332. [CrossRef] [PubMed]

13. Feng, L.; Wang, W.; Cheng, J.; Ren, Y.; Zhao, G.; Gao, C.; Tang, Y.; Liu, X.; Han, W.; Peng, X.; et al. Genome and proteome of long-chain alkane degrading Geobacillus thermodenitrificans NG80-2 isolated from a deep-subsurface oil reservoir. Proc. Natl. Acad. Sci. USA 2007, 104, 5602-5607. [CrossRef] [PubMed]

14. Liu, C.; Wang, W.; Wu, Y.; Zhou, Z.; Lai, Q.; Shao, Z. Multiple alkane hydroxylase systems in a marine alkane degrader, Alcanivorax dieselolei B-5. Environ. Microbiol. 2011, 13, 1168-1178. [CrossRef] [PubMed]

15. Funhoff, E.G.; Bauer, U.; Garcia-Rubio, I.; Witholt, B.; van Beilen, J.B. CYP153A6, a soluble P450 oxygenase catalyzing terminal-alkane hydroxylation. J. Bacteriol. 2006, 188, 5220-5227. [CrossRef] [PubMed]

16. Martínková, L.; Uhnáková, B.; Pátek, M.; Nešvera, J.; Křen, V. Biodegradation potential of the genus Rhodococcus. Environ. Int. 2009, 35, 162-177. [CrossRef]

17. Sameshima, Y.; Honda, K.; Kato, J.; Omasa, T.; Ohtake, H. Expression of Rhodococcus opacus alkB genes in anhydrous organic solvents. J. Biosci. Bioeng. 2008, 106, 199-203. [CrossRef]

18. Amouric, A.; Quemeneur, M.; Grossi, V.; Liebgott, P.P.; Auria, R.; Casalot, L. Identification of different alkane hydroxylase systems in Rhodococcus ruber strain SP2B, an hexane-degrading actinomycete. J. Appl. Microbiol. 2010, 108, 1903-1916. [CrossRef]

19. Cappelletti, M.; Fedi, S.; Frascari, D.; Ohtake, H.; Turner, R.J.; Zannoni, D. Analyses of both the alkB gene transcriptional start site and alkB promoter-inducing properties of Rhodococcus sp. strain BCP1 grown on n-alkanes. Appl. Environ. Microbiol. 2011, 77, 1619-1627. [CrossRef]

20. Takei, D.; Washio, K.; Morikawa, M. Identification of alkane hydroxylase genes in Rhodococcus sp. strain TMP2 that degrades a branched alkane. Biotechnol. Lett. 2008, 30, 1447-1452. [CrossRef]

21. Whyte, L.G.; Smits, T.H.; Labbe, D.; Witholt, B.; Greer, C.W.; van Beilen, J.B. Gene cloning and characterization of multiple alkane hydroxylase systems in Rhodococcus strains Q15 and NRRL B-16531. Appl. Environ. Microbiol. 2002, 68, 5933-5942. [CrossRef] [PubMed]

22. Lo Piccolo, L.; De Pasquale, C.; Fodale, R.; Puglia, A.M.; Quatrini, P. Involvement of an alkane hydroxylase system of Gordonia sp. strain SoCg in degradation of solid n-alkanes. Appl. Environ. Microbiol. 2011, 77, 1204-1213. [CrossRef] [PubMed]

23. Quatrini, P.; Scaglione, G.; De Pasquale, C.; Riela, S.; Puglia, A.M. Isolation of Gram-positive $n$-alkane degraders from a hydrocarbon-contaminated Mediterranean shoreline. J. Appl. Microbiol. 2008, 104, 251-259. [CrossRef] [PubMed]

24. Seto, M.; Masai, E.; Ida, M.; Hatta, T.; Kimbara, K.; Fukuda, M.; Yano, K. Multiple polychlorinated biphenyl transformation systems in the gram-positive bacterium Rhodococcus sp. strain RHA1. Appl. Environ. Microbiol. 1995, 61, 4510-4513. [PubMed]

25. Seto, M.; Kimbara, K.; Shimura, M.; Hatta, T.; Fukuda, M.; Yano, K. A novel transformation of polychlorinated biphenyls by Rhodococcus sp. strain RHA1. Appl. Environ. Microbiol. 1995, 61, 3353-3358. 
26. Iwasaki, T.; Miyauchi, K.; Masai, E.; Fukuda, M. Multiple-subunit genes of the aromatic-ring-hydroxylating dioxygenase play an active role in biphenyl and polychlorinated biphenyl degradation in Rhodococcus sp. strain RHA1. Appl. Environ. Microbiol. 2006, 72, 5396-5402. [CrossRef]

27. Mathieu, J.M.; Mohn, W.W.; Eltis, L.D.; LeBlanc, J.C.; Stewart, G.R.; Dresen, C.; Okamoto, K.; Alvarez, P.J. 7-ketocholesterol catabolism by Rhodococcus jostii RHA1. Appl. Environ. Microbiol. 2010, 76, 352-355. [CrossRef]

28. Patrauchan, M.A.; Florizone, C.; Eapen, S.; Gómez-Gil, L.; Sethuraman, B.; Fukuda, M.; Davies, J.; Mohn, W.W.; Eltis, L.D. Roles of ring-hydroxylating dioxygenases in styrene and benzene catabolism in Rhodococcus jostii RHA1. J. Bacteriol. 2008, 190, 37-47. [CrossRef]

29. Sharp, J.O.; Sales, C.M.; LeBlanc, J.C.; Liu, J.; Wood, T.K.; Eltis, L.D.; Mohn, W.W.; Alvarez-Cohen, L. An inducible propane monooxygenase is responsible for $N$-nitrosodimethylamine degradation by Rhodococcus sp. strain RHA1. Appl. Environ. Microbiol. 2007, 73, 6930-6938. [CrossRef]

30. Araki, N.; Niikura, Y.; Miyauchi, K.; Kasai, D.; Masai, E.; Fukuda, M. Glucose-mediated transcriptional repression of PCB/biphenyl catabolic genes in Rhodococcus jostii RHA1. J. Mol. Microb. Biotech. 2011, 20, 53-62. [CrossRef]

31. Yanisch-Perron, C.; Vieira, J.; Messing, J. Improved M13 phage cloning vectors and host strains: Nucleotide sequences of the M13mp18 and pUC19 vectors. Gene 1985, 33, 103-119. [CrossRef]

32. Simon, R.; Priefer, U.; Pühler, A. A broad host range mobilization system for in vivo genetic engineering: Transposon mutagenesis in gram negative bacteria. Nat. Biotechnol. 1983, 1, 784-791. [CrossRef]

33. Studier, F.W.; Moffatt, B.A. Use of bacteriophage T7 RNA polymerase to direct selective high-level expression of cloned genes. J. Mol. Biol. 1986, 189, 113-130. [CrossRef]

34. Short, J.M.; Fernandez, J.M.; Sorge, J.A.; Huse, W.D. $\lambda$ ZAP: A bacteriophage $\lambda$ expression vector with in vivo excision properties. Nucleic Acids Res. 1988, 16, 7583-7600. [CrossRef] [PubMed]

35. Schäfer, A.; Tauch, A.; Jäger, W.; Kalinowski, J.; Thierbach, G.; Pühler, A. Small mobilizable multi-purpose cloning vectors derived from the Escherichia coli plasmids pK18 and pK19: Selection of defined deletions in the chromosome of Corynebacterium glutamicum. Gene 1994, 145, 69-73. [CrossRef]

36. Hashimoto, Y.; Nishiyama, M.; Yu, F.; Watanabe, I.; Horinouchi, S.; Beppu, T. Development of a host-vector system in a Rhodococcus strain and its use for expression of the cloned nitrile hydratase gene cluster. J. Gen. Microbiol. 1992, 138, 1003-1010. [CrossRef]

37. Masai, E.; Yamada, A.; Healy, J.M.; Hatta, T.; Kimbara, K.; Fukuda, M.; Yano, K. Characterization of biphenyl catabolic genes of gram-positive polychlorinated biphenyl degrader Rhodococcus sp. strain RHA1. Appl. Environ. Microbiol. 1995, 61, 2079-2085.

38. Kasai, D.; Fujinami, T.; Abe, T.; Mase, K.; Katayama, Y.; Fukuda, M.; Masai, E. Uncovering the protocatechuate 2,3-cleavage pathway genes. J. Bacteriol. 2009, 191, 6758-6768. [CrossRef]

39. van der Geize, R.; Hessels, G.I.; van Gerwen, R.; van der Meijden, P.; Dijkhuizen, L. Unmarked gene deletion mutagenesis of kstD, encoding 3-ketosteroid $\Delta^{1}$-dehydrogenase, in Rhodococcus erythropolis SQ1 using sacB as counter-selectable marker. FEMS Microbiol. Lett. 2001, 205, 197-202. [CrossRef]

40. Goncalves, E.R.; Hara, H.; Miyazawa, D.; Davies, J.E.; Eltis, L.D.; Mohn, W.W. Transcriptomic assessment of isozymes in the biphenyl pathway of Rhodococcus sp. strain RHA1. Appl. Environ. Microbiol. 2006, 72, 6183-6193. [CrossRef]

41. Sleight, S.C.; Bartley, B.A.; Lieviant, J.A.; Sauro, H.M. In-Fusion BioBrick assembly and re-engineering. Nucleic Acids Res. 2010, 38, 2624-2636. [CrossRef] [PubMed]

42. Kamimura, N.; Takamura, K.; Hara, H.; Kasai, D.; Natsume, R.; Senda, T.; Katayama, Y.; Fukuda, M.; Masai, E. Regulatory system of the protocatechuate 4,5-cleavage pathway genes essential for lignin downstream catabolism. J. Bacteriol. 2010, 192, 3394-3405. [CrossRef] [PubMed]

43. van Beilen, J.B.; Neuenschwander, M.; Smits, T.H.; Roth, C.; Balada, S.B.; Witholt, B. Rubredoxins involved in alkane oxidation. J. Bacteriol 2002, 184, 1722-1732. [CrossRef] [PubMed]

44. Shanklin, J.; Achim, C.; Schmidt, H.; Fox, B.G.; Münck, E. Mössbauer studies of alkane omega-hydroxylase: Evidence for a diiron cluster in an integral-membrane enzyme. Proc. Natl. Acad. Sci. USA 1997, 94, 2981-2986. [CrossRef]

45. Shanklin, J.; Whittle, E.; Fox, B.G. Eight histidine residues are catalytically essential in a membrane-associated iron enzyme, stearoyl-CoA desaturase, and are conserved in alkane hydroxylase and xylene monooxygenase. Biochemistry 1994, 33, 12787-12794. [CrossRef] 
46. van Beilen, J.B.; Penninga, D.; Witholt, B. Topology of the membrane-bound alkane hydroxylase of Pseudomonas oleovorans. J. Biol. Chem. 1992, 267, 9194-9201.

47. van Beilen, J.B.; Smits, T.H.; Roos, F.F.; Brunner, T.; Balada, S.B.; Rothlisberger, M.; Witholt, B. Identification of an amino acid position that determines the substrate range of integral membrane alkane hydroxylases. J. Bacteriol. 2005, 187, 85-91. [CrossRef]

48. Tani, A.; Ishige, T.; Sakai, Y.; Kato, N. Gene structures and regulation of the alkane hydroxylase complex in Acinetobacter sp. strain M-1. J. Bacteriol. 2001, 183, 1819-1823. [CrossRef]

49. Canosa, I.; Yuste, L.; Rojo, F. Role of the alternative sigma factor $\sigma S$ in expression of the AlkS regulator of the Pseudomonas oleovorans alkane degradation pathway. J. Bacteriol. 1999, 181, 1748-1754.

50. Canosa, I.; Sanchez-Romero, J.M.; Yuste, L.; Rojo, F. A positive feedback mechanism controls expression of AlkS, the transcriptional regulator of the Pseudomonas oleovorans alkane degradation pathway. Mol. Microbiol. 2000, 35, 791-799. [CrossRef]

51. Ramos, J.L.; Martínez-Bueno, M.; Molina-Henares, A.J.; Terán, W.; Watanabe, K.; Zhang, X.; Gallegos, M.T.; Brennan, R.; Tobes, R. The TetR family of transcriptional repressors. Microbiol. Mol. Biol. Rev. 2005, 69, 326-356. [CrossRef]

52. Pompeani, A.J.; Irgon, J.J.; Berger, M.F.; Bulyk, M.L.; Wingreen, N.S.; Bassler, B.L. The Vibrio harveyi master quorum-sensing regulator, LuxR, a TetR-type protein is both an activator and a repressor: DNA recognition and binding specificity at target promoters. Mol. Microbiol. 2008, 70, 76-88. [CrossRef]

53. George, A.M.; Levy, S.B. Gene in the major cotransduction gap of the Escherichia coli K-12 linkage map required for the expression of chromosomal resistance to tetracycline and other antibiotics. J. Bacteriol. 1983, 155, 541-548.

54. Orth, P.; Schnappinger, D.; Hillen, W.; Saenger, W.; Hinrichs, W. Structural basis of gene regulation by the tetracycline inducible Tet repressor-operator system. Nat. Struct. Biol. 2000, 7, 215-219. [CrossRef]

55. Cuthbertson, L.; Nodwell, J.R. The TetR family of regulators. Microbiol. Mol. Biol. Rev. 2013, 77, 440-475. [CrossRef]

(C) 2019 by the authors. Licensee MDPI, Basel, Switzerland. This article is an open access article distributed under the terms and conditions of the Creative Commons Attribution (CC BY) license (http://creativecommons.org/licenses/by/4.0/). 